J. Clin. Chem. Clin. Biochem.

Vol. 28, 1990, pp. 817-824

(C) 1990 Walter de Gruyter \& Co.

Berlin · New York

\title{
A Candidate Reference Method for Coupled Sodium-Water Determination in Human Serum
}

\author{
By J. D. E. van Suijlen, C. A. Berrevoets and B. Leijnse
}

Department of Clinical Chemistry, Academic Hospital Dijkzigt, Rotterdam, The Netherlands

(Received February 26/July 6, 1990)

\begin{abstract}
Summary: A candidate reference method is described for coupled sodium-water determination based on ionexchange sodium separation from the serum matrix followed by gravimetry as $\mathrm{Na}_{2} \mathrm{SO}_{4}$, and serum water determination by means of microwave evaporation. For sera with normal sodium and water contents, the mean relative standard deviation is $0.6 \%(0.8 \mathrm{mmol} / \mathrm{l})$. Mean inaccuracy for the coupled sodium-water determination is $-0.3 \%(0.4 \mathrm{mmol} / \mathrm{l})$. The candidate reference method can be considered a reference method because the reference method value did not differ significantly from the definitive value, there is no known source for interferences or bias, and misinterpretation due to abnormal protein or lipid levels is excluded because serum sodium is determined on a plasma water basis. Sodium concentrations determined by the candidate reference method are used for comparing field methods with the candidate reference method. If the resulting regression equation is used in the calibration procedure, good correlation between all (in)direct field methods and the candidate reference method is ensured, and accurate results are produced. Results of proficiency testing show a good correlation between (in)direct field methods and the candidate reference method, because sera with approximately normal water contents are used.
\end{abstract}

\section{Introduction}

In clinical chemistry, the sodium concentration in serum is determined by flame atomic emission spectrometry (FAES) or (in)direct ion-selective electrode analysers (ISEs). In direct ISE methods the activity of free sodium ions in serum water is determined, whereas in traditional FAES methodology and indirect ISE measurement the total sodium concentration in serum after dilution of the sample is measured (1). In all but direct ISE measurement, assay values are sensitive to the serum volume occupied by proteins and lipids. This sensitivity may lead to misinterpretation of electrolyte status (pseudohyponatraemia) (2, 3) if serum samples with abnormal protein and/or lipid concentrations are determined. Hence it is stated that the interpretation of sample data should be based on measurement of sodium activity (direct ISE) which is insensitive to the serum volume diplaced by dispersed or dissolved solids $(1,4)$. Experience with direct
ISE analysers has shown that the results obtained on one sample may differ significantly from one instrument to another $(5,6)$. These differences caused by broad variation in instrument design and calibration solutions make comparison of data very difficult, so that direct ISE is not suitable as an accuracy base (reference method) for sodium measurement. Since confusion also exists concerning the quantity to be reported by direct ISEs (activity or concentration), the European Working Group on ISEs (EWGISE) of the IFCC Expert Panel on pH, Blood Gases and Electrolytes, has proposed that all instruments should report results of sodium measurement as concentrations (mmol/l plasma) that agree with those obtained by FAES measurement in normal plasma samples (7). To date, instrument manufacturers produce direct ISE analysers which mathematically convert sodium activity into sodium concentration with theoretically the same numerical value as that obtained by FAES measurement, for the analysis of normal serum (4). 
However, flame photometers (even if internal standard instruments are used) are subject to inherent bias from e. g. flame temperature, viscosity, surface tension and matrix effects. In order to exclude possible misinterpretation, data should also be expressed on a plasma-water basis (8).

We describe the development of a candidate reference method for coupled sodium-water determination based on ion-exchange sodium separation from the serum matrix followed by gravimetry as $\mathrm{Na}_{2} \mathrm{SO}_{4}$, and serum water determination by means of microwave evaporation. The procedure is based on a modification of the The National Institute of Standards and Technology (NIST, formerly NBS) definitive method for the determination of sodium in serum (9) and an improved version of a new water determination developed in our laboratory (10).

Finally, we used this method to evaluate the accuracy of field methods in use in our clinical chemistry laboratory and to study the accuracy of consensus values in proficiency testing.

\section{Materials and Methods}

\section{Materials}

\subsection{Water}

Twice distilled water with a specific resistance $>10 \mathrm{k} \Omega \cdot \mathrm{m}$ at $25^{\circ} \mathrm{C}$ was used.

\subsection{Reagents}

Sodium, potassium, lithium standard solutions: standard solutions were prepared from Standard Reference Materials Sodium Chloride (SRM 919), Potassium Chloride (SRM 918) and Lithium Carbonate (SRM 924), National Institute of Standards and Technology (NIST), Washington, D. C., USA. The SRMs were dried by heating at $110^{\circ} \mathrm{C}$ for four hours and stored in a desiccator for 1 hour before use.

Hydrochloric acid $8.2 \mathrm{~mol} / \mathrm{l}$, "suprapur", max. 0.5 parts per million $(\mathrm{mg} / \mathrm{kg}$ ) sodium, sulphuric acid $9.8 \mathrm{~mol} / \mathrm{l}$, "suprapur", max. $0.1 \mathrm{mg} / \mathrm{kg}$ sodium, nitric acid $10.3 \mathrm{~mol} / \mathrm{l}$, "suprapur", max. $0.1 \mathrm{mg} / \mathrm{kg}$ sodium, and boric acid "suprapur" were obtained from Merck, Darmstadt, FRG.

All other reagents were of analytical grade.

\subsection{Accuracy assessment}

Standard Reference Material 909 (SRM 909), human serum, was obtained from the National Institute of Standards and Technology, Washington, D. C., USA.

Lyophilysed horse serum for clinical chemical use (RIVM high component concentrations), was obtained from the Dutch National Institute for Public Health (RIVM), Bilthoven, the Netherlands.

1.4 Control sera from the Dutch Quality Assessment Foundation (SKZL), Nijmegen, the Netherlands

No. 90 A/B; 14-12-87: Nycomed Autonorm 2244/2280, No. 91 A/B; 01-02-88: Biotrol,
No. 92 A/B; 05-04-88: Boehringer Mannheim Precinorm/path, No. 93 A/B; 06-06-88: Seronorm 179/Pathonorm H-22,

No. 94 A/B; 15-09-88: Autonorm 2362/2361,

No. 95 A/B; 10-10-88: Technicon Testpoint 1/2,

No. 96 A/B; 05-12-88: Fisher Serachem,

No. 97 A/B; 30-01-89: Seronorm (human)/Lyotrol N-X, No. 98 A/B; 03-04-89: Precinorm/Precipath and No. 99 A/B; 29-05-89: R. I. V. M. (human).

\subsection{Ion-exchange resin and chromatographic columns}

AG 50W-X8, 100-200 mesh, a strongly acidic cation exchange resin, and econo-columns, $1.0 \times 30.0 \mathrm{~cm}$, were obtained from Bio-Rad Laboratories, Richmond/CA, USA.

\subsection{Routine sodium analysers}

Flame atomic emission spectrometry: IL 943, Instrumentation Laboratory (Benelux), Ysselstein, the Netherlands.

Indirect ion-selective electrode analysers: RA1000 and CHEM 1, Technicon, Tarrytown/NY, USA.

Direct potentiometric electrode analysers: ACA III, Dupont de Nemours, Wilmington/DE, USA and Corning 614, Ciba Corning Diagnostics, Halstead/Essex, U. K.

All instruments were calibrated and used according to the manufacturers' instructions.

\subsection{Microwave oven}

Philips AVM. Cooktronic 706/PH, 1.3 kw, $2450 \mathrm{MHz}$, Philips, the Netherlands.

\subsection{Containers}

All volumetric glassware was of borosilicate material, conforming to class A specifications. Teflon beakers used were from TPX Azlon, Labplex, U. K. ( 50 and $250 \mathrm{ml}$ beakers were used).

\subsection{Balance}

Sartorius 2462 analytical balance $(\mathrm{d}=0.1 \mathrm{mg})$, Göttingen, FRG.

\section{Methods}

\subsection{Cleaning of the containers}

All containers were soaked for $60 \mathrm{~min}$ in $0.75 \mathrm{~mol} / 1$ nitric acid and afterwards rinsed 5 times with twice distilled water. The containers were dried at room temperature and used immediately after drying.

\subsection{Sampling}

To minimize sampling errors, standard and serum samples were weighed. Aliquots were converted from weight to volume, using the density of each standard or serum sample, measured with a pycnometer $(5.00 \mathrm{ml})$.

\subsection{Weighing procedure}

All standards and samples were weighed until constant weight: maximal allowed weight difference between two subsequent weighings $0.0005 \mathrm{~g}$. Usually two subsequent weighings were sufficient to achieve constant weight. 


\subsection{Sodium determination}

a) Ion-exchange separation

- Approximately $8 \mathrm{ml}$ of sample is weighed into a teflon beaker $(50 \mathrm{ml})$ and diluted with distilled water to about $25 \mathrm{ml}$.

- The sample is loaded onto the column using a peristaltic pump and teflon tubing. For complete transfer, the teflon beaker is washed with $25 \mathrm{ml}$ distilled water, the washing solution is completely transferred onto the column. This washing procedure is repeated twice, so that $100 \mathrm{ml}$ distilled water is used for complete transfer and for washing nonionogenic matter from each column.

- Elution is started with $0.4 \mathrm{~mol} / 1 \mathrm{HCl}$, flow $60 \mathrm{ml} / \mathrm{h}$. Fraction collection is started after detection of the first acidic effluent.

- Fractions 0-75 $\mathrm{ml}$ (fraction A) and $75-255 \mathrm{ml}$ (fraction B) are collected in $250 \mathrm{ml}$ teflon beakers.

- The resin is regenerated with $100 \mathrm{ml} 5 \mathrm{~mol} / 1 \mathrm{HCl}$ and washed with $75 \mathrm{ml}$ distilled water.

- Fractions $\mathrm{A}$ and $\mathrm{B}$ are evaporated on a hot plate to about $10 \mathrm{ml}\left(8-12\right.$ hours at $\left.100^{\circ} \mathrm{C}\right)$.

- Fraction A is examined by FAES to determine the presence of sodium. If present, the determination is rejected.

b) Gravimetric determination

- A platinum crucible (with cover) is heated for $15 \mathrm{~min}$ at $700{ }^{\circ} \mathrm{C}$ and weighed after $15 \mathrm{~min}$ cooling in a desiccator. This procedure is repeated until constant weight is achieved.

- The concentrated fraction B is transferred quantitatively to the previously weighed crucible.

- $1 \mathrm{ml}$ sulphuric acid $(1 \mathrm{~mol} / \mathrm{l})$ is added (via the crucible wall) and the sample is evaporated on a hot plate. After cooling for $15 \mathrm{~min}$ in a desiccator, this procedure is repeated twice; the last time the crucible is partly covered with the platinum lid.

- The crucible (covered with lid) is slowly heated from 400$700{ }^{\circ} \mathrm{C}$, and held at $700{ }^{\circ} \mathrm{C}$ for $15 \mathrm{~min}$.

- After cooling for $15 \mathrm{~min}$ in a desiccator, $1 \mathrm{ml}$ ammonium carbonate $(15.8 \%)$ is added (via crucible wall) and slowly evaporated to dryness on a hot plate.

- The sample is again heated for $15 \mathrm{~min}$ at $700{ }^{\circ} \mathrm{C}$, cooled 15 $\min$ in a desiccator and weighed.

- The last 2 steps are repeated until constant weight is achieved.

Calculation:

$\mathrm{Na}[\mathrm{mmol} / \mathrm{l}]=\frac{\text { yield } \mathrm{Na}_{2} \mathrm{SO}_{4}[\mathrm{mg}] \cdot 2 \cdot \text { density }[\mathrm{g} / \mathrm{l}]}{M_{\mathrm{r}}\left(\mathrm{Na}_{2} \mathrm{SO}_{4}\right)[\mathrm{g} / \mathrm{mol}] \cdot \text { sample weight }[\mathrm{g}]}$.

\section{Remarks}

All samples are analysed in duplicate. The maximal allowed difference between duplicate measurements is $0.9 \mathrm{mmol} / \mathrm{l}$. If this limit is exceeded, an additional measurement must be performed.

In sera with extremely elevated lithium levels $(>1.5 \mathrm{mmol} / \mathrm{l})$ separation of lithium and sodium may not be complete (see results). For this reason the precipitate is dissolved in $10.00 \mathrm{ml}$ distilled water, analysed for lithium with the NIST reference method (11), and corrected if necessary. So far, this has never been necessary in our determinations.
Before use, the ion-exchange column must be regenerated until constant column height $(28 \pm 0.5 \mathrm{~cm})$ is achieved. This step is performed twice.

Normally two working days are needed for the determination of one reference method value, and four columns can be handled efficiently by one technician.

\subsection{Water determination}

- All samples are analysed in duplicate, the maximal allowable difference between duplicate measurements being 0.0010 $\mathrm{kg} / \mathrm{l}$. If this limit is exceeded, an additional measurement must be performed.

- A glass petri dish (with cover) is irradiated for $3 \mathrm{~min},(2 \mathrm{~min}$ at $175 \mathrm{~W}, 1 \mathrm{~min}$ at $575 \mathrm{~W}$ ), cooled $30 \mathrm{~min}$ in a desiccator (containing calcium sulphate as desiccant) and weighed.

- This procedure is repeated until constant weight is achieved (M1).

- Approximately $1 \mathrm{ml}$ of sample is weighed into the glass petri dish and immediately hereafter it is weighed again (M2).

- $0.5 \mathrm{ml}$ ethanol is added and after gently swirling the petri dish, the dish is placed (uncovered) into the microwave oven.

- The petri dish is again irradiated for $3 \mathrm{~min}$, cooled $30 \mathrm{~min}$ in a desiccator and weighed.

- This procedure is repated until constant weight is achieved (M3).

Calculation:

$$
\mathrm{H}_{2} \mathrm{O}[\mathrm{kg} / \mathrm{l}]=\frac{\mathrm{M} 2[\mathrm{~g}]-\mathrm{M} 3[\mathrm{~g}]}{\mathrm{M} 2[\mathrm{~g}]-\mathrm{M} 1[\mathrm{~g}]} \times \text { density }[\mathrm{kg} / \mathrm{l}] .
$$

The accuracy of the water determination was investigated according to the following procedure:

-4 vials of control serum are stored overnight in a desiccator.

- The vials are weighed (W1), $5.00 \mathrm{ml}$ of distilled water is added and the vials are weighed again (W2).

- After determination of density and water content (see 2.5; four determinations per vial) the vials are washed with distilled water, dried, stored overnight in a desiccator and weighed again (W3).

Calculation of water content:

$$
\mathrm{H}_{2} \mathrm{O}[\mathrm{kg} / \mathrm{l}]=\frac{\mathrm{W} 2[\mathrm{~g}]-\mathrm{W} 1[\mathrm{~g}]}{\mathrm{W} 2[\mathrm{~g}]-\mathrm{W} 3[\mathrm{~g}]} \times \text { density }[\mathrm{kg} / \mathrm{l}]
$$

\subsection{Interference study}

The possible interference of lithium and potassium was studied by determination of the sodium content in standard solutions containing different amounts of lithium $(0.5-2.5 \mathrm{mmol} / \mathrm{l})$ and potassium $(5-50 \mathrm{mmol} / \mathrm{l})$ but the same (weighed in) sodium concentration. In combination with these measurements, the influence of sodium-bicarbonate complex formation and sodium-protein binding on the assay results was investigated. Three solutions were prepared:

Solution A: $0.9368 \mathrm{~g}$ sodium chloride in distilled water, Solution B: $0.9380 \mathrm{~g}$ sodium chloride in $0.05 \mathrm{~mol} / 1 \mathrm{LiOH} /$ $\mathrm{H}_{3} \mathrm{BO}_{3}$,

Solution C: $1.3506 \mathrm{~g}$ sodium bicarbonate in $0.05 \mathrm{~mol} / 1 \mathrm{LiOH} /$ $\mathrm{H}_{3} \mathrm{BO}_{3}$. 
The sodium concentration in A was determined according to the protocol in 2.4 after incubation ( 2 hours at room temperature) with $75 \mathrm{~g} / 1$ purified human albumin. Reference method values are corrected for sodium present in the albumin fraction.

The sodium concentration in $\mathrm{B}$ and $\mathrm{C}$ was measured by FAES (8) after separation on the ion-exchange column using $1 \mathrm{~mol} / \mathrm{l}$ $\mathrm{LiCl}$ in $\mathrm{LiOH}$ boric acid buffer $(\mathrm{pH}=8.2)$. All samples are measured in duplicate on two consecutive days.

\subsection{Expression of the sodium concentration in serum}

The sodium concentration measured by the candidate reference method is divided by the measured water content and expressed as molality or substance concentration in the water phase ( $\mathrm{mmol} / \mathrm{kg}$ serum water).

If this value is multiplied by the normal serum water value $(\mathrm{kg} / \mathrm{l})(12)$, the reported value is thus corrected for abnormal water content and is called the standard sodium concentration (mmol/1 serum).

\subsection{Statistical analysis}

Inter-assay comparison was made by regression analysis according to Passing \& Bablok (13). Significance between means of series of assay determinations was calculated with the Student's paired t-test (significant difference if $\mathrm{p}<0.05$ ).

\section{Results}

\section{Precision}

The imprecision of the sodium determination was calculated after twelve measurements on each of two human serum pools. The mean relative standard deviation of the candidate reference method value was $0.52 \%$ at the $120-140 \mathrm{mmol} / \mathrm{l}$ level (tab. 1). For calculation of the precision of the water determination, twenty measurements on two human serum pools were used. The mean relative standard deviation was $0.09 \%$ (tab. 2). These results indicate a mean imprecision of the coupled sodium water determination of approximately $0.6 \%(0.8 \mathrm{mmol} / \mathrm{l})$ for sera with normal sodium and water contents.

Tab. 1. Precision of the sodium determination.

\begin{tabular}{|c|c|c|c|}
\hline Control serum & $\begin{array}{l}\text { Mean candidate } \\
\text { reference method } \\
\text { value } \mathrm{mmol} / \mathrm{l}\end{array}$ & $\begin{array}{l}\mathrm{SD} \\
\mathrm{mmol} / \mathrm{l}\end{array}$ & $\begin{array}{l}\mathrm{CV} \\
\%\end{array}$ \\
\hline Human serum pool A & 141.0 & 0.66 & 0.47 \\
\hline Human serum pool B & 121.1 & 0.68 & 0.56 \\
\hline
\end{tabular}

Tab. 2. Precision of the water determination.

\begin{tabular}{llll}
\hline Control serum & $\begin{array}{l}\text { Mean candidate } \\
\text { reference method } \\
\text { value kg/l }\end{array}$ & $\mathrm{SD}$ & $\mathrm{CV}$ \\
\hline Human serum pool C & 0.9401 & $\%$ \\
\hline Human serum pool D & 0.9288 & 0.0007 & 0.08 \\
\hline
\end{tabular}

\section{Accuracy}

The accuracy of the sodium determination was investigated with twelve measurements on a standard solution and four measurements on NBS SRM 909. The mean candidate reference method value for the standard solutions is $147.4 \mathrm{mmol} / \mathrm{l}$ (range 146.8-148.7 $\mathrm{mmol} / \mathrm{l}$ ), which equals the weighed-in value. The mean candidate reference method value for SRM 909 differed by $-0.3 \%$ from the definitive value, and all four values were within the confidence limits of the definitive value given by NIST (tab. 3).

The accuracy of the water determination was investigated according to the procedure mentioned in the methods section. The mean measured water content differed by $-0.01 \%$ (range $-0.03-0.04 \%$ ) from the calculated value (tab. 4). Mean inaccuracy for the coupled sodium water determination therefore is approximately $-0.3 \%(0.4 \mathrm{mmol} / \mathrm{l})$ with the SRM 909 .

\section{Interference study}

Sodium measurement is not influenced by potassium concentrations up to $50 \mathrm{mmol} / \mathrm{l}$ and lithium concentrations up to $1.5 \mathrm{mmol} / \mathrm{l}$ (results not shown). If the lithium concentration in a serum sample exceeds 1.5 $\mathrm{mmol} / \mathrm{l}$, separation between lithium and sodium is not complete and reference method values are biased by lithium sulphate precipitation.

Binding of sodium to protein and bicarbonate at physiological $\mathrm{pH}$ has been reported in the literature $(14,15)$, and this would be expected to increase with increasing $\mathrm{pH}$. Because there is no significant decrease in measured sodium value after incubation with human serum albumin under the reaction conditions (solution A) and at $\mathrm{pH}=8.2$ (solution B) (tab. 5), the candidate reference method can be considered to determine both bound and unbound sodium in human serum. At $\mathrm{pH}=8.2$ approximately $5 \%$ of the sodium present is bound to bicarbonate. Our results (tab. 5, solution $\mathrm{C}$ ) indicate, as expected, that all bicarbonatebound sodium is also determined with the candidate reference method, because no significant difference between measured and calculated sodium concentration can be detected.

\section{Comparison with routine procedures}

Each day, during a period of eighteen days, we analysed two patient samples in duplicate with the candidate reference method and the routine procedures used in our department. The samples $(n=36)$ were selected on the basis of routine measurement and encompassed sodium concentrations between 125 and 
Tab. 3. Accuracy of the sodium determination.

\begin{tabular}{lllr}
\hline Control sample & $\begin{array}{l}\text { Definitive sodium value } \\
\text { (95\% confidence limit) } \\
\text { mmol/l }\end{array}$ & $\begin{array}{l}\text { Candidate reference } \\
\text { method value } \\
\text { mmol/l }\end{array}$ & $\begin{array}{l}\text { Difference } \\
\%\end{array}$ \\
\hline Standard solution & 147.4 & 147.4 & 0.00 \\
SRM 909 A & $134.2(133.4-135.1)$ & 133.5 & -0.52 \\
SRM 909 B & $134.2(133.4-135.1)$ & 134.1 & -0.08 \\
SRM 909 C & $134.2(133.4-135.1)$ & 133.8 & -0.29 \\
SRM 909 D & $134.2(133.4-135.1)$ & 134.0 & -0.15 \\
\hline
\end{tabular}

Tab. 4. Accuracy of the water determination.

\begin{tabular}{llll}
\hline $\begin{array}{l}\text { Control } \\
\text { serum }\end{array}$ & $\begin{array}{l}\mathrm{H}_{2} \mathrm{O} \\
\text { calculated } \\
\mathrm{kg} / \mathrm{l}\end{array}$ & $\begin{array}{l}\mathrm{H}_{2} \mathrm{O} \\
\text { measured } \\
\mathrm{kg} / \mathrm{l}\end{array}$ & $\begin{array}{l}\text { Difference } \\
\%\end{array}$ \\
\hline Vial 1 & 0.9374 & 0.9371 & -0.03 \\
Vial 2 & 0.9366 & 0.9368 & 0.02 \\
Vial 3 & 0.9357 & 0.9357 & 0.00 \\
Vial 4 & 0.9452 & 0.9456 & 0.04 \\
\hline
\end{tabular}

Tab. 5. Influence of sodium protein binding and bicarbonate complex formation on candidate reference method values.

\begin{tabular}{lllr}
\hline Solution & $\begin{array}{l}\text { Na calculated } \\
\mathrm{mmol} / \mathrm{l}\end{array}$ & $\begin{array}{l}\text { Na measured } \\
\mathrm{mmol} / \mathrm{l}\end{array}$ & $\begin{array}{l}\text { Binding } \\
\%\end{array}$ \\
\hline $\mathrm{A}$ & 160.3 & 160.9 & $\begin{array}{r}0.37 \\
\end{array}$ \\
$\mathrm{~B}$ & 160.5 & 159.8 & -0.32 \\
& & 160.2 & -0.19 \\
$\mathrm{C}$ & 160.8 & 161.0 & 0.31 \\
& & 161.0 & 0.12 \\
& & 160.4 & -0.25 \\
\hline
\end{tabular}

$160 \mathrm{mmol} / \mathrm{l}$ and protein concentrations between 57 and $80 \mathrm{~g} / \mathrm{l}$. Mean water content was $0.9369 \mathrm{~kg} / \mathrm{l}$ (range $0.9221-0.9436 \mathrm{~kg} / \mathrm{l}$ ). Table 6 presents the regression data of comparison between candidate reference method sodium molality and routine method values (sodium molarity). A comparison of free molal concentration (by direct ISE; ACA III and Corning 614) and total molal concentration (by the proposed candidate reference method) is presented in table 7. Finally, candidate reference method standard sodium concentrations (molarity) are compared with the corresponding routine method values.

\section{Proficiency testing}

Using the data base of the Dutch external quality control program (SKZL) we studied the accuracy of the consensus value of sixteen external quality control sera in three selected methods. Consensus values for FAES, direct ISE and indirect ISE were compared with the candidate reference method values. Consensus values agreed well with the candidate reference

Tab. 6. Method comparison $(y=a x+b)$ between candidate reference method sodium molality $(x)$ and routine method value (y).

\begin{tabular}{|c|c|c|c|c|c|c|}
\hline \multirow[t]{2}{*}{ Method } & \multirow[t]{2}{*}{ A } & \multirow[t]{2}{*}{ B } & \multicolumn{2}{|c|}{$95 \%$ confidence limit } & \multirow{2}{*}{$\begin{array}{l}\text { Mean y } \\
\mathrm{mmol} / \mathrm{l}\end{array}$} & \multirow{2}{*}{$\begin{array}{l}\text { Mean x } \\
\mathrm{mmol} / \mathrm{kg}\end{array}$} \\
\hline & & & $\mathrm{A}$ & B & & \\
\hline IL 943 & 0.9400 & -1.6 & $0.8696-1.0127$ & $-12.2-9.3$ & 141.2 & 151.5 \\
\hline CHEM 1 & 0.9199 & 0.7 & $0.8511-1.0127$ & $-12.9-11.3$ & 140.5 & 151.5 \\
\hline RA 1000 & 0.9916 & -7.7 & $0.8871-1.0938$ & $-23.2-8.2$ & 142.7 & 151.5 \\
\hline ACA III & 0.9091 & 3.3 & $0.8411-0.9870$ & $-8.8-13.5$ & 140.9 & 151.5 \\
\hline CORNING 614 & 0.9091 & 2.9 & $0.8421-0.9998$ & $-10.9-13.0$ & 140.7 & 151.5 \\
\hline
\end{tabular}

Tab. 7. Method comparison $(y=a x+b)$ between candidate reference method total sodium molality $(x)$ and free sodium molality measured by direct ISE.

\begin{tabular}{|c|c|c|c|c|c|c|c|}
\hline \multirow[t]{2}{*}{ Method } & \multirow[t]{2}{*}{ A } & \multirow[t]{2}{*}{$\mathrm{B}$} & \multicolumn{2}{|c|}{$95 \%$ confidence limit } & \multirow{2}{*}{$\begin{array}{l}\text { Mean y } \\
\mathrm{mmol} / \mathrm{l}\end{array}$} & \multirow{2}{*}{$\begin{array}{l}\text { Mean x } \\
\text { mmol/kg }\end{array}$} & \multirow[t]{2}{*}{$\mathrm{p}$ value } \\
\hline & & & $\mathrm{A}$ & B & & & \\
\hline ACA III & 0.9734 & 2.1 & $0.8934-1.0422$ & $-6.2-11.8$ & 150.8 & 151.5 & 0.218 \\
\hline CORNING 614 & 0.9804 & 2.1 & $0.9004-1.0641$ & $-9.9-10.4$ & 151.2 & 151.5 & 0.175 \\
\hline
\end{tabular}


Tab. 8. Method comparison $(y=a x+b)$ between candidate reference method standard sodium concentration ( $x$ ) and routine method value $(y)$.

\begin{tabular}{|c|c|c|c|c|c|c|c|}
\hline \multirow[t]{2}{*}{ Method } & \multirow[t]{2}{*}{ A } & \multirow[t]{2}{*}{ B } & \multicolumn{2}{|c|}{$95 \%$ confidence limit } & \multirow{2}{*}{$\begin{array}{l}\text { Mean y } \\
\text { mmol/1 }\end{array}$} & \multirow{2}{*}{$\begin{array}{l}\text { Mean x } \\
\text { mmol/1 }\end{array}$} & \multirow[t]{2}{*}{$\mathrm{p}$ value } \\
\hline & & & $\mathrm{A}$ & B & & & \\
\hline IL 943 & 1.0066 & -1.2 & $0.9346-1.0909$ & $-12.7-9.3$ & 141.2 & 141.0 & 0.520 \\
\hline CHEM 1 & 0.9890 & 0.7 & $0.9160-1.0909$ & $-13.4-11.1$ & 140.5 & 141.0 & 0.100 \\
\hline RA 1000 & 1.0682 & -8.1 & $0.9524-1.1732$ & $-22.9-8.2$ & 142.7 & 141.0 & 0.001 \\
\hline ACA III & 0.9813 & 2.5 & $0.9028-1.0599$ & $-8.7-13.6$ & 140.9 & 141.0 & 0.593 \\
\hline CORNING 614 & 0.9819 & 2.2 & $0.9036-1.0753$ & $-11.0-13.0$ & 140.7 & 141.0 & 0.284 \\
\hline
\end{tabular}

method values (tab. 8). The mean bias of FAES was $-0.3 \%$ (range $-3.8-2.8 \%$ ), and of indirect ISE $-0.1 \%$ (range $-3.3-2.2 \%$ ). A negative bias was found when the water content was low (samples 98A and $\mathrm{B}$ ), and a positive bias when the water content was high (sample 96A). Consensus values from direct ISE differed on average by $-0.4 \%$ (range $-1.2-$ $1.4 \%$ ) from the candidate reference method value.

\section{Discussion}

Good agreement between direct (ISE) and indirect (ISE and FAES) determinations is found in samples in which protein and lipid, and therefore, serum water concentrations are normal. The expected differences are found with samples which contain abnormally low or high levels of protein and lipids (and therefore an abnormal water concentration). In these samples, indirect methods give results which are susceptible to clinical misinterpretation.

Approaches which seek to correct flame photometric and indirect ISE sodium determinations by measurement of total protein and/or lipids in serum (8) or by measuring serum water (10) gain ready acceptance in clinical chemistry laboratories (16). These methods vary in performance and generally exhibit a bias versus each other, thus indicating the need for all sodium measurements (both direct and indirect) to be performed on a serum-water concentration basis. Our method provides the necessary accuracy base, i. e. a candidate reference method for coupled sodium-water determination. This candidate reference method can be considered a reference method for the following reasons.

- The candidate reference method sodium value did not differ significantly from the definitive value given by NIST, and mean imprecision and inaccuracy for the coupled sodium water determination are below the limits set by the Expert Commission on Electrolytes (1 SD imprecision limit of 1.5 $\mathrm{mmol} / \mathrm{l}$ and a maximum difference from the definitive value of $2.0 \mathrm{mmol} / \mathrm{l}$ for serum sodium at the $140 \mathrm{mmol} / 1$ level) (9),
- There is no known source of interferences or systematic errors (bias), mainly because the sodium ion is separated from the matrix,

- It produces results which approximate to the "true value" (total sodium value) within narrow limits because all sodium in serum (free ions as well as bound to protein or bicarbonate) is determined.

- Misinterpretation due to abnormal protein or lipid levels is excluded because reported values are expressed as sodium molality or as sodium molarity after correction for abnormal water content.

Reference method values should be the basis of quality assessment in clinical chemistry (17). This new concept was evaluated by using the candidate reference method to establish the accuracy of field methods for sodium by comparative testing and the accuracy of method-dependent consensus values in a Dutch external quality control programme.

Our results (tab. 6) show that if analytically preferable results (sodium molality) are considered in the method comparison, there is a significant difference between the mean values of the sera used for comparison ( $p<0.001$, paired t-test) in all methods. Both direct ISE methods (ACA III and Corning 614) also show significant differences in the slope of the regression equation. The direct ISE methods were, however, calibrated to read similar values to a flame photometer. We therefore reset all correlation factors and compared free sodium molality (assuming normal water contents and activity coefficient) to total sodium molality (by the proposed candidate reference method). The results presented in table 7 show no significant difference in slope and (or) intercept.

It is argued that it would be physiologically desirable to measure sodium activity instead of molality. Although there is an analytical and statistical difference between activity and molality, clinically these differences are not significant (4). The major advantage of sodium molality measurement is that it provides for an accuracy base (the described candidate reference method) which is absent in (direct ISE) sodium activ- 
ity measurement. A disadvantage of presentation of sample data as sodium molality is that high capacity instruments are needed to determine the water content if indirect field methods are used. Because these instruments are not available and reference ranges would be significantly different from those currently used, the most practical solution is to correct the candidate reference method sodium concentration for possible abnormal water contents.

The sodium concentration measured by the candidate reference method is divided by the measured water content and multiplied by the normal serum water value $(\mathrm{kg} / \mathrm{l})$. The reported value is therefore the sodium concentration that would be measured if the serum water concentrations were normal, and it is called the standard sodium concentration. Because this "water correction" is used, current reference ranges can still be used and misinterpretation due to abnormal protein or lipid levels is still impossible.

These standard sodium concentrations are used for the method comparison presented in tab. 8. The results show that in fact only the RA 1000 produces inaccurate results, and therefore is not properly calibrated. Using the regression equation resulting from method comparison, the RA 1000 was programmed to set slope to 1.0 with an intercept of 0 against the candidate reference method. After this calibration procedure (18), results were in good correlation with standard candidate reference method values $(\mathrm{y}=0.9914 \mathrm{x}+0.3, \mathrm{p}=0.234)$.

Calibrating (in)direct field methods in the way described ensures that field method values are similar to the candidate reference method values, if samples with normal protein and lipid levels are used. Because inter-method comparability is increased and more accurate assay results are produced, this method comparison procedure should be used in all field methods in addition to the calibration procedure mentioned by the manufacturers.

As mentioned, the candidate reference method is also used to establish the accuracy of method-dependent consensus values in a Dutch external quality control programme. The expected differences are found in samples which contain abnormally low (96A) or high (98A and B) protein and or lipid levels.

According to the new German Guidelines based on reference method values and medical requirements (19), sodium determinations may differ maximally by $6 \%$ from the reference method value. Since the maximal difference from the candidate reference method value is only $3.8 \%$ and mean differences are less than $0.5 \%$ (tab. 9), all methods are considered valid for sodium measurement according to the German Guidelines. It has to be mentioned, however, that individual measurements may differ by more than $6 \%$ from the candidate reference method value, especially if abnormal protein and or lipid levels are present.

The candidate reference method might be used to determine the urgently needed reference method values of sodium in serum on a plasma water basis. If the regression equation of comparison against the candidate reference method is used for calibration of field methods, all samples which contain abnormally high levels of protein and or lipids will still, if indirect

Tab. 9. Comparison of candidate reference method standard sodium concentration with method-dependent consensus values.

\begin{tabular}{|c|c|c|c|c|c|c|c|c|}
\hline \multirow{3}{*}{$\begin{array}{l}\text { Control } \\
\text { serum }\end{array}$} & \multirow{3}{*}{$\begin{array}{l}\left(\mathrm{H}_{2} \mathrm{O}\right. \\
\mathrm{kg} / \mathrm{l})\end{array}$} & \multirow{3}{*}{$\begin{array}{l}\text { Candidate } \\
\text { reference } \\
\text { method } \\
\text { value } \mathrm{A} \\
\text { mmol/1 }\end{array}$} & \multicolumn{6}{|c|}{ Method-dependent consensus values } \\
\hline & & & \multicolumn{2}{|l|}{ FAES } & \multicolumn{2}{|c|}{ ISE direct } & \multicolumn{2}{|c|}{ ISE indirect } \\
\hline & & & $\begin{array}{l}\text { value B } \\
\text { mmol/1 }\end{array}$ & $\begin{array}{c}(\mathrm{B}-\mathrm{A}) / \mathrm{A} \\
\times 100 \%\end{array}$ & $\begin{array}{l}\text { value C } \\
\mathrm{mmol} / 1\end{array}$ & $\begin{array}{c}(\mathrm{C}-\mathrm{A}) / \mathrm{A} \\
\times 100 \%\end{array}$ & $\begin{array}{l}\text { value D } \\
\mathrm{mmol} / \mathrm{l}\end{array}$ & $\begin{array}{c}(\mathrm{D}-\mathrm{A}) / \mathrm{A} \\
\times 100 \%\end{array}$ \\
\hline $90 \mathrm{~A}$ & $(0.9333)$ & 133.7 & 134.1 & 0.3 & 133.8 & 0.1 & 134.4 & 0.5 \\
\hline $90 \mathrm{~B}$ & $0.9320)$ & 148.6 & 148.4 & -0.1 & 150.3 & 1.1 & 149.3 & 0.5 \\
\hline $91 \mathrm{~A}$ & $(0.9362)$ & 144.0 & 145.2 & 0.8 & 144.0 & 0.0 & 145.1 & 0.8 \\
\hline $91 \mathrm{~B}$ & $(0.9221)$ & 155.3 & 154.8 & -0.3 & 155.1 & -0.1 & 154.9 & -0.3 \\
\hline $93 \mathrm{~A}$ & $(0.9447)$ & 134.8 & 135.4 & 0.4 & 145.7 & 0.7 & 135.2 & 0.3 \\
\hline $93 \mathrm{~B}$ & $(0.9268)$ & 161.7 & 160.8 & -0.6 & 162.5 & 0.5 & 160.6 & -0.7 \\
\hline $94 \mathrm{~A}$ & $(0.9384)$ & 126.5 & 128.4 & 1.5 & 125.0 & -1.2 & 128.1 & 1.3 \\
\hline $94 B$ & $(0.9283)$ & 145.5 & 145.1 & -0.3 & 146.4 & 0.6 & 145.1 & -0.3 \\
\hline $95 \mathrm{~A}$ & $(0.9585)$ & 115.6 & 116.3 & 0.6 & 116.9 & 1.1 & 117.0 & 1.2 \\
\hline $95 \mathrm{~B}$ & $(0.9350)$ & 147.5 & 146.3 & -0.8 & 148.3 & 0.5 & 147.1 & -0.3 \\
\hline $96 \mathrm{~A}$ & $(0.9591)$ & 118.3 & 121.6 & 2.8 & 118.0 & -0.3 & 120.9 & 2.2 \\
\hline $96 \mathrm{~B}$ & $(0.9322)$ & 147.2 & 147.5 & 0.2 & 146.1 & -0.7 & 147.5 & 0.2 \\
\hline $98 \mathrm{~A}$ & $(0.9117)$ & 128.8 & 123.9 & -3.8 & 129.7 & 0.7 & 124.6 & -3.3 \\
\hline $98 B$ & $(0.9173)$ & 141.6 & 136.8 & -3.4 & 143.6 & 1.4 & 138.0 & -2.5 \\
\hline $99 \mathrm{~A}$ & $(0.9445)$ & 116.5 & 114.7 & -1.5 & 118.1 & 1.4 & 115.2 & -1.1 \\
\hline $99 B$ & $(0.9475)$ & 144.1 & 143.8 & -0.2 & 144.8 & 0.5 & 144.9 & 0.6 \\
\hline
\end{tabular}


measured, give results which are susceptible to clinical misinterpretation. Both indirect and direct measurements are suitable for use in patient management, provided the indirect measurements are corrected for abnormal water content. The development of high capacity instruments for water determination in human serum is therefore desirable. Meanwhile, it must be kept in mind that for most patient samples indirect

\section{References}

1. Maas, A. H. J., Siggaard-Andersen, O., Weisberg, H. F. \& Zijlstra, W. G. (1985) Ion-selective electrodes for sodium and potassium: A new problem of what is measured and what should be reported. Clin. Chem. 31, 482-485.

2. Ladenson, J. H., Apple, F. S., Aguanno, J. J. \& Koch, D. D. (1982) Sodium measurements in multiple myeloma: two techniques compared. Clin. Chem. 28, 2383-2386.

3. Albrink, M. J., Hald, P. M., Man, E. B. \& Peters, J. P. (1955) The displacement of serum water by the lipids of hyperlipemic serum. A new method for the rapid determination of serum water. J. Clin. Invest. 34, 1482-1488.

4. Worth, H. G. J. (1985) A comparison of the measurement of sodium and potassium by flame photometry and ionselective electrode. Ann. Clin. Biochem. 22, 343-350.

5. Oesch, U., Ammann, D. \& Simon, W. (1986) Ion-selective membrane electrodes for clinical use. Clin. Chem. 32, $1448-1459$.

6. Burnett, D., Ayers, G. J., Rumjen, S. C. \& Woods, T. F. (1988) Sodium measurements in the presence of paraproteins by four direct ISE methods and flame photometry compared. Ann. Clin. Biochem. 25, 102-109.

7. Boink, A. B. T. J., Buckley, B. M., Christiansen, T. F., Covington, A. K., Maas, A. H. J., Mueller-Plathe, O., Sachs, Ch. \& Siggaard-Andersen, O. (1986) Ion-selective electrode measurements of sodium and potassium in undiluted serum, plasma or whole blood: recommendations for expression of results in clinical practice. In: Proceedings of the 4th Meeting of the European Working Group on Ion Selective Electrodes, pp. 237-238, Radiometer, Copenhagen.

8. Waugh, W. H. (1969) Utility of expressing serum sodium per unit of water in assessing hyponatremia. Metabolism $18,706-712$.

9. Velapoldi, R. A., Paule, R. C., Schaffer, R., Mandel, J. \& Moddy, J. R. (1978) Standard reference materials: A reference method for the determination of sodium in serum. N. V.S. Special Publication 260-269. and direct measurement correlate well, and clinically important differences are found in only a few cases.

\section{Acknowledgement}

The authors wish to thank Dr. B. G. Blijenberg for critical reading of the manuscript and Dr. $H$. Baadenhuijsen for supplying control sera from the Dutch Quality Assessment Foundation.
10. van Kreel, B. K., Wulkan, R. W. \& Leijnse, B. L. (1988) Serum water determination by means of microwave evaporation. J. Clin. Chem. Clin. Biochem. 26, 579-581.

11. Velapoldi, R. A., Paule, R. C., Schaffer, R., Mandel, J., Machlan, L. A., Garner, E. L. \& Rains, T. C. (1980) Standard reference materials: A reference method for the determination of lithium in serum. N. B.S. Special Publication $260-269$.

12. Broughton, P. M. G., Smith, S. C. H. \& Buckley, B. M. (1985) Calibration of direct ion-selective electrodes for plasma $\mathrm{Na}^{+}$to allow for the influence of protein concentration. Clin. Chem. 31, 806.

13. Passing, H. \& Bablok, W. (1983) A new biomedical procedure for testing the equality of measurements from two different analytical methods. J. Clin. Chem. Clin. Biochem. $21,709-720$.

14. Carr, C. W. (1956) Studies on the binding of small ions in protein solutions with the use of membrane electrodes. VI. The binding of sodium and potassium ions in solutions of various proteins. Arch. Biochem. Biophys. 62, 476-484.

15. Coleman, R. L. \& Young, C. C. (1981) Evidence for formation of bicarbonate complexes with $\mathrm{Na}$ and $\mathrm{K}$ under physiological conditions. Clin. Chem. 27, 1938-1939.

16. Faye, S. \& Payne, R. B. (1986) Rapid measurement of serum water to assess pseudohyponatremia. Clin. Chem. $32,983-986$.

17. Stamm, D. (1982) A new concept for quality control of clinical laboratory investigations in the light of clinical requirements and based on reference method values. J. Clin. Chem. Clin. Biochem. 20, 817-824.

18. Russel, L. J., Smith, S. C. H. \& Buckley, B. M. (1988) Plasma sodium and potasium measurements: minimising ISE-flame differences using specimens from patients. Ann. Clin. Biochem. 25, 96-101.

19. Anonymous (1988) Qualitätssicherung der quantitativen Bestimmungen im Laboratorium. Neue Richtlinien der Bundesärztekammer. Dt. Ärztebl. 85, B517-B531.

Drs. J. D. E. van Suijlen

Academic Hospital Dijkzigt

Department of Clinical Chemistry

Dr. Molewaterplein 40

NL-3015 GD Rotterdam 